\title{
Decreased Gene Expressions of Insulin Signal Molecules in Canine Hyperadrenocorticism
}

\author{
Satoshi NOZAWA ${ }^{1,2)}$, Hitomi ODA ${ }^{2)}$, Ran AKIYAMA ${ }^{2)}$, Kaori UEDA ${ }^{2)}$, Kaori SAEKI ${ }^{2)}$, Saori SHONO2), \\ Natsuki MARUYAMA ${ }^{2)}$, Atsuki MURATA ${ }^{1)}$, Hiroyuki TAZAKI ${ }^{1)}$, Akihiro MORI ${ }^{2)}$, Yutaka MOMOTA ${ }^{2)}$, \\ Daigo AZAKAMI ${ }^{2)}$, Toshinori $\mathrm{SAKO}^{2)}$ and Katsumi ISHIOKA ${ }^{2) *}$ \\ 1)Laboratory of Biomolecular Chemistry, School of Veterinary Medicine, Faculty of Veterinary Science, Nippon Veterinary and Life \\ Science University, 1-7-1 Kyonan-cho, Musashino-shi, Tokyo 180-8602, Japan \\ ${ }^{2)}$ Department of Veterinary Nursing, School of Veterinary Nursing and Technology, Faculty of Veterinary Science, Nippon Veterinary and \\ Life Science University, 1-7-1 Kyonan-cho, Musashino-shi, Tokyo 180-8602, Japan
}

(Received 16 January 2014/Accepted 25 April 2014/Published online in J-STAGE 15 May 2014)

ABSTRACT. Hyperadrenocorticism (HAC) is a common endocrine disorder in dogs, in which excess glucocorticoid causes insulin resistance. Disturbance of insulin action may be caused by multiple factors, including transcriptional modulation of insulin signal molecules which lie downstream of insulin binding to insulin receptors. In this study, gene expressions of insulin signal molecules were examined using neutrophils of the HAC dogs (the untreated dogs and the dogs which had been treated with trilostane). Insulin receptor substrate (IRS)-1, IRS-2, phosphatidylinositol 3-kinase (PI3-K), protein kinase B/Akt kinase (Akt)-2 and protein kinase C (PKC)-lambda were analyzed in the HAC dogs and compared with those from normal dogs. The IRS-1 gene expressions decreased by $37 \%$ and $35 \%$ of the control dogs in the untreated and treated groups, respectively. The IRS-2 gene expressions decreased by $61 \%$ and $72 \%$, the PI3-K gene expressions decreased by $47 \%$ and $55 \%$, and the Akt-2 gene expressions decreased by $45 \%$ and $56 \%$ of the control dogs, similarly. Collectively, gene expressions of insulin signal molecules are suppressed in the HAC dogs, which may partially contribute to the induction of insulin resistance. KEY WORDS: canine, hyperadrenocorticism, insulin signal molecules, neutrophils

doi: 10.1292/jvms.14-0033; J. Vet. Med. Sci. 76(8): 1177-1182, 2014

Hyperadrenocorticism (HAC) is an endocrine disease which shows hyper-glucocorticoids in humans and dogs. Physiologically, glucocorticoids are produced in adrenal cortex under the control of hypothalamic-pituitary-adrenal axis and modulate carbohydrate metabolism [1, 11]. Glucocorticoids are inducers of insulin resistance, which defined as impaired sensitivity to the effects of insulin on carbohydrate metabolism, so the hyper-glucocorticoid is a significant risk factor of diabetes mellitus (DM) also in dogs $[31,33]$. In rodents, corticosterone, which is a rodents' major glucocorticoid, does antagonistic actions on insulin, and increased plasma glucose concentrations had been observed in the corticosterone-treated rodents [7, 24, 29, 32]. Insulin stimulates glucose uptake via translocation of glucose transporter (GLUT)-4 from intracellular vesicles to cellular membranes in insulin-sensitive tissues (liver, skeletal muscle, adipose tissue, etc.). In human and rodent studies, excess glucocorticoids have shown to antagonize insulin action by inhibiting insulin-mediated glucose uptake and utilization by insulin-sensitive tissues [5, 16]. When

*Correspondence to: Ishioka, K., Department of Veterinary Nursing, School of Veterinary Nursing and Technology, Faculty of Veterinary Science, Nippon Veterinary and Life Science University, 1-7-1 Kyonan-cho, Musashino-shi, Tokyo 180-8602, Japan. e-mail: katsumi@nvlu.ac.jp

(C)2014 The Japanese Society of Veterinary Science

This is an open-access article distributed under the terms of the Creative Commons Attribution Non-Commercial No Derivatives (by-nc-nd) License $<$ http://creativecommons.org/licenses/by-nc-nd/3.0/>. insulin binds to its receptors, the receptor becomes tyrosinephosphorylated form and activates insulin receptor substrate (IRS) -1, 2, 3 and 4. Phosphorylated tyrosine on the IRS proteins binds to the $\mathrm{p} 85$ regulatory subunits of phosphatidylinositol 3' kinase (PI3-K), which is a heterodimer of a regulatory subunit (p85) and a catalytic subunit (p110) [9]. Recent reports indicate that the serine/threonine protein kinase protein kinase $\mathrm{B}$ (PKB; also known as Akt) and atypical protein kinase $\mathrm{C}$ (aPKC, $\mathrm{PKC}$-lambda and -gamma) mediate the downstream events controlled by PI3-K and Akt-2, which are enriched in insulin-sensitive tissues and have been specifically implicated in the metabolic actions of the hormone $[6,17,40]$. The initial report suggesting that aPKC is required for insulin-stimulated glucose transport describes that inactive (dominant-negative) forms of these protein kinases cause inhibitory effects on insulin action in adipocytes and muscular cells [3, 19, 38, 44]. In our previous report, we measured glucose infusion rates (GIR) of HAC dogs by euglycemic-hyperinsulinemic glucose clamp (EHGC) method using an artificial pancreas apparatus [15]. EHGC method [12] is a gold standard for assessing insulin resistance in human skeletal muscles [18]. When GIR in the HAC dogs were compared with those in normal dogs, the HAC dogs showed lower GIR than normal ones, indicating that the HAC dogs are suffering from insulin resistance as well as human patients [15]. The mechanism of insulin resistance may include transcriptional, translational and activational modulations of insulin signal molecules. Currently, we focused on the transcriptional level, so measured gene expressions of IRS-1, IRS-2, PI3-K, Akt-2 and PKC-lambda 
Table 1. Profiles of the dogs

\begin{tabular}{|c|c|c|c|c|c|c|c|c|c|}
\hline \multirow{2}{*}{ No. } & \multirow{2}{*}{ Classification } & \multirow{2}{*}{ Breeds } & \multirow{2}{*}{$\begin{array}{c}\text { Age } \\
\text { (years) }\end{array}$} & \multirow{2}{*}{ Gender } & \multicolumn{2}{|c|}{$\begin{array}{l}\text { Cortisol concentration } \\
(\mu \mathrm{g} / \mathrm{d} l)\end{array}$} & \multicolumn{2}{|c|}{$\begin{array}{l}\text { Adrenal glands } \\
\text { sizes }(\mathrm{mm})\end{array}$} & \multirow{2}{*}{ Clinical signs } \\
\hline & & & & & $\begin{array}{l}\text { pre ACTH } \\
\text { stimulation }\end{array}$ & $\begin{array}{l}\text { post ACTH } \\
\text { stimulation }\end{array}$ & Right & Left & \\
\hline 1 & \multirow[t]{8}{*}{ Control } & Beagle & 3 & Spayed & $<1$ & 14.1 & 4.6 & 4.9 & no sign \\
\hline 2 & & Beagle & 3 & Spayed & $<1$ & N.A. & 5.6 & 4.4 & no sign \\
\hline 3 & & Beagle & 3 & Castrated & 1.26 & 14.3 & N.D. & 4.0 & no sign \\
\hline 4 & & Beagle & 2 & Castrated & $<1$ & 11.7 & N.D. & 4.9 & no sign \\
\hline 5 & & Beagle & 2 & Castrated & 1.11 & 15.7 & N.D. & 3.6 & no sign \\
\hline 6 & & Beagle & 2 & Spayed & 1.02 & 16.7 & N.D. & 4.0 & no sign \\
\hline 7 & & Beagle & 6 & Spayed & 2.11 & 10.6 & N.D. & N.D. & no sign \\
\hline 8 & & Beagle & 6 & Spayed & 1.78 & 9.39 & 4.8 & 4.3 & no sign \\
\hline 9 & \multirow{4}{*}{$\begin{array}{c}\text { HAC } \\
\text { (untreated) }\end{array}$} & Toy Poodle & 6 & Castrated & 13.0 & 29.2 & 3.9 & 3.3 & PU/PD, polyphagia, dermatologic problem \\
\hline 10 & & Portuguese Water Dog & 8 & Castrated & 8.80 & 30.3 & 12.8 & 10.9 & PU/PD, polyphagia, dermatologic problem \\
\hline 11 & & Tiny Poodle & 13 & Female & 5.75 & 56.2 & 6.0 & 7.8 & PU/PD, decreased activity, panting \\
\hline 12 & & Yorkshire Terrier & 4 & Spayed & 16.5 & 46.4 & 5.5 & 7.3 & PU/PD, dermatologic problem, decreased activity \\
\hline 14 & \multirow[t]{6}{*}{$\begin{array}{c}\mathrm{HAC} \\
\text { (treated) }\end{array}$} & Miniature Dachshund & 14 & Castrated & $3.22(8.60)$ & $6.15(37.1)$ & (7.6) & $(5.4)$ & $\begin{array}{l}\text { dermatologic problem, decreased activity, pendulous } \\
\text { abdomen }\end{array}$ \\
\hline 15 & & Maltese & 10 & Female & $2.21(15.6)$ & $5.90(39.8)$ & $(10.7)$ & $(9.6)$ & PU/PD, polyphagia, dermatologic problem \\
\hline 16 & & Miniature Dachshund & 12 & Female & $1.85(9.07)$ & $2.98(23.4)$ & $(6.6)$ & $(5.9)$ & PU/PD, polyphagia, dermatologic problem \\
\hline 17 & & Miniature Dachshund & 11 & Castrated & $1.95(2.80)$ & $5.62(45.5)$ & $(8.5)$ & $(10.2)$ & polyphagia, dermatologic problem, pendulous abdomen \\
\hline 18 & & Mix & 7 & Spayed & $3.70(7.50)$ & $8.60(31.5)$ & $(9.8)$ & $(8.2)$ & PU/PD, polyphagia, dermatologic problem \\
\hline 19 & & Pug & 11 & Female & $3.57(5.75)$ & $7.81(53.3)$ & $(7.0)$ & (7.6) & PU/PD, polyphagia, dermatologic problem \\
\hline
\end{tabular}

HAC, Hyperadrenocorticism; PU/PD, polyuria polydipsia; N.A., not applicable; N.D., not detectable.

In the treated HAC group, the cortisol concentrations and the sizes of adrenal glands noted in brackets are those at diagnosis (before treatments).

in the HAC dogs to reveal a possible mechanism of insulin resistance in HAC dogs. Demonstrating such mechanisms may lay out the pathophysiology of canine HAC and will be of help in exploring therapeutic strategy.

Eight beagles ( 3 castrated males and 5 spayed females, 2-6 years old) maintained in our laboratory were used as the control dogs. These dogs did not show any clinical signs and significant pathological variations in blood biochemistry (data not shown). Serum cortisol concentrations after ACTH administration were lower than $20 \mu \mathrm{g} / \mathrm{d} l$ in control dogs (Table 1). Eleven client-owned dogs suffering from HAC, visiting our veterinary medical teaching hospital, constituted the HAC group. Their profiles, serum cortisol concentrations and size of adrenal glands are shown in Table 1. All animals have not received glucocorticoids for medical or research purposes before the examinations. Diagnosis of $\mathrm{HAC}$ was confirmed on the basis of clinical signs and the ACTH stimulation test. Dogs were included in the study when at least 3 clinical signs of HAC (polyuria-polydipsia [PU/PD], polyphagia, dermatologic problems, decreased activity, panting and pendulous abdomen) were detected. A cortisol concentration of $>20 \mu \mathrm{g} / \mathrm{d} l$ in the sample obtained $1 \mathrm{hr}$ after ACTH administration was considered abnormal and consistent with HAC. In addition, the adrenal glands were examined using ultrasonography. The HAC dogs were divided to two groups, such as the untreated dogs and the treated dogs which had been received medical treatments with trilostane. Serum cortisol concentrations after ACTH administration in the untreated dogs were higher than 20 $\mu \mathrm{g} / \mathrm{d} l$. By contrst, those in the treated dogs were lower than $20 \mu \mathrm{g} / \mathrm{d} l$, while they had been higher than $20 \mu \mathrm{g} / \mathrm{d} l$ before they received the treatment (Table 1). Approval for this work has been given by the Nippon Veterinary and Life Science University Animal Research Committee.

The blood samples were collected into EDTA-2K tubes. Neutrophils were separated from whole blood in accordance with a previous report [27]. The yield of neutrophils by this method is $>95 \%$, both in our laboratory and in the previous report. Total RNA was extracted from the neutrophils using a commercial kit (QIAamp RNA Blood Mini, QIAGEN, Tokyo, Japan) and stored at $-80^{\circ} \mathrm{C}$ until the assay. Quantitative real-time (qRT) PCR analysis was performed to compare the mRNA levels of insulin signal molecules in peripheral neutrophils. Total RNA samples were reverse-transcribed into cDNA using a QuantiTect Rev. Transcription Kit (QIAGEN). The primers were designed to the targeted genes using the sequences information (Table 2). The qRT-PCR reactions for each gene of interest were performed in triplicate. The reactions were carried out with a commercial kit (Perfect Real Time SYBR Premix Ex Taq II) using an Applied Biosystems 7300 Real Time PCR Sequence Detection System (Applied Biosystems, Foster City, CA, U.S.A.). The protocol was as follows, $94^{\circ} \mathrm{C}$ for $10 \mathrm{sec}$, followed by 40 cycles of $95^{\circ} \mathrm{C}$ for $5 \mathrm{sec}$ and $60^{\circ} \mathrm{C}$ for $34 \mathrm{sec}$. Following amplification, a melting curve analysis program was performed to verify the authenticity of the amplified products by their specific melting temperatures (Applied Biosystems). The resulting products were subjected to nucleotide sequencing to confirm their specificity. PCR amplification was carried out in $20 \mu l$ solutions containing $1 \mu l$ of template cDNA, $0.8 \mu l$ of each specific primer $(10 \mu \mathrm{M}), 10 \mu l$ of SYBR Premix Ex Taq, $0.4 \mu l$ ROX reference dyeII and $7.0 \mu l$ of distilled water. 
Table 2. Primer sequences

\begin{tabular}{|c|c|c|c|c|}
\hline Target & $\begin{array}{l}\text { Expected size of the } \\
\text { PCR product (bp) }\end{array}$ & Primer type & Sequence $\left(5^{\prime}-3^{\prime}\right)$ & GenBank Acc. No. \\
\hline beta-actin & 129 & $\begin{array}{l}\text { Forward } \\
\text { Reverse }\end{array}$ & $\begin{array}{l}\text { gccaaccgtgagaagatgact } \\
\text { cccagagtccatgacaataccag }\end{array}$ & AF021873 \\
\hline IRS-1 & 81 & $\begin{array}{l}\text { Forward } \\
\text { Reverse }\end{array}$ & $\begin{array}{l}\text { acctgcgttcaaggaggtctg } \\
\text { cggtagatgccaatcaggttc }\end{array}$ & XM543274 \\
\hline IRS-2 & 177 & $\begin{array}{l}\text { Forward } \\
\text { Reverse }\end{array}$ & $\begin{array}{l}\text { tggcaggtgaacctgaagc } \\
\text { gaagaagaagctgtccgagtgg }\end{array}$ & XM542667 \\
\hline PI3-K & 132 & $\begin{array}{l}\text { Forward } \\
\text { Reverse }\end{array}$ & $\begin{array}{l}\text { gcattaaaccagacctcattcagc } \\
\text { gcgagtattggtcttcagtgttctc }\end{array}$ & AB436616 \\
\hline Akt-2 & 180 & $\begin{array}{l}\text { Forward } \\
\text { Reverse }\end{array}$ & $\begin{array}{l}\text { ctcgagtatttgcattcgag } \\
\text { acctggcacccgaggtgctg }\end{array}$ & NM001012340 \\
\hline PKC-lambda & 135 & $\begin{array}{l}\text { Forward } \\
\text { Reverse }\end{array}$ & $\begin{array}{l}\text { gctctgataacccggatcaa } \\
\text { cctttgggtccttgttgaga }\end{array}$ & XM535855 \\
\hline
\end{tabular}

After qRT-PCR amplification, absolute quantification was performed according to the method of Whelan et al. [47], by establishing a linear amplification curve from 10-fold serial dilutions of cloned and sequenced plasmid DNA containing target PCR products. The expression level of the beta-actin gene as a housekeeping gene was quantified by the same method, and the expression levels of the target genes were rectified by the expression level of the beta-actin gene. Each value of mRNA expression was denoted as the relative value of the control group.

Values were expressed as means \pm standard errors of the mean (SEM). For statistical analyses among the groups, Kruskal-Wallis test was employed using Graph Pad Prism 5.2 (GraphPad Software, La Jolla, CA, U.S.A.).

The results of the gene expressions of insulin signal molecules, such as IRS-1, IRS-2, PI3-K, Akt-2 and PKClambda, examined in the 8 normal dogs, the 5 untreated HAC dogs and the 6 treated HAC dogs are shown in Fig. 1. IRS- 1 mRNA expressions decreased by $37 \%$ in the untreated HAC dogs and $35 \%$ in the treated HAC dogs comparing to the control dogs, but the differences were not statistically significant. IRS-2 mRNA expressions decreased by $61 \%$ in the untreated HAC dogs and $72 \%$ in the treated HAC dogs comparing to the control dogs, and the difference in the treated HAC dogs was statistically significant $(P<0.01)$. PI3-K mRNA expressions decreased by $47 \%$ in the untreated HAC dogs and $55 \%$ in the treated HAC dogs comparing to the control dogs, and the difference in the treated HAC dogs was statistically significant $(P<0.05)$. Akt 2 mRNA expressions decreased by $45 \%$ in the untreated HAC dogs and $56 \%$ in the treated HAC dogs comparing to the control dogs, and the difference in the treated HAC dogs was statistically significant $(P<0.05)$. PKC-lambda mRNA expressions did not change in both the untreated HAC dogs and the treated HAC dogs comparing to the control dogs.

As the mechanism of insulin resistance, there are multiple possibilities, such as decreased mRNAs (at transcriptional level), decreased proteins (at translational level), decreased phosphorylation (at activational level) of signal molecules and/or inhibition by other factors. In the present study, we focused on the transcriptional level, so we measured gene expressions of the insulin signal molecules (IRS-1, IRS-2, PI3-K, Akt-2 and PKC-lambda) in HAC dogs and compared them to those in normal dogs. Currently, we used leukocytes for analysis, which are insulin-target cells [10, 14, 21, 28, 35 ], and insulin regulates glycolytic enzymes and GLUT translocations in leukocytes [23]. Actually, we have demonstrated that leukocytes reflect the gene expressions in other insulin-sensitive tissues, such as liver, skeletal muscle and abdominal fat, in a previous paper [25]. Total leukocytes were used in the previous study, but we used only neutrophils in this study, because glucocorticoids increase a number of peripheral neutrophils and decreases lymphocytes and then the proportion of leukocytes may change.

In the present study, IRS-1 and IRS-2 expressions were suppressed in the HAC dogs, as shown in Fig. 1. These molecules are ubiquitously expressed proteins, which are located in the head stream of insulin signal cascade [2, 30, 48, 49]. There are some reports which have described the effects of glucocorticoids on insulin signaling in rodents, i.e., decrease in phosphorylated IRS-1 and increase in phosphorylated IRS-2 levels in vitro $[8,36]$ and decrease in phosphorylated IRS-2 levels in vivo $[4,37,39,46]$. In other reports, IRS$1 /-2$ decreased in the liver and skeletal muscle of diabetic humans showing insulin resistance and $o b / o b$ mice with type 2 diabetes [42, 43]. Furthermore, IRS-2 knocked out mice showed diabetic symptoms [20]. In the veterinary field, we have reported that IRS-2 proteins in the skeletal muscle, adipose tissue, liver and leukocytes of obese cats showed lower expression levels than those in normal cats $[22,26]$. As for the cat, obesity is regarded as a risk factor of DM onset like human beings [34]. PI3-K and Akt-2 mRNA expressions in the HAC dogs significantly decreased. It has been reported that the mRNA expressions of Akt-2 were suppressed in cultured murine ovarian cells when dexamethasone was applied into the medium [45]. This report harmonizes the present result, in which the Akt-2 mRNA expressions decreased in the dogs with higher cortisol levels. In the current results, the insulin signal molecules had remained suppressed even after the HAC was treated. These findings square with a previous study, in which insulin sensitivity has been decreased in human HAC patients, and it has continued even after the 
IRS-1
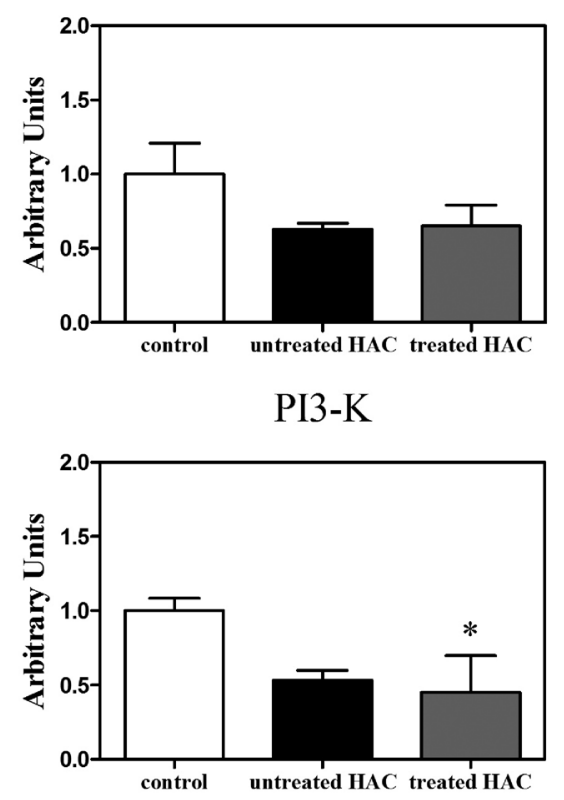

IRS-2

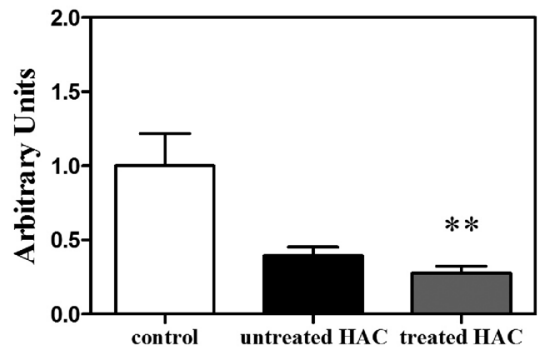

Akt-2

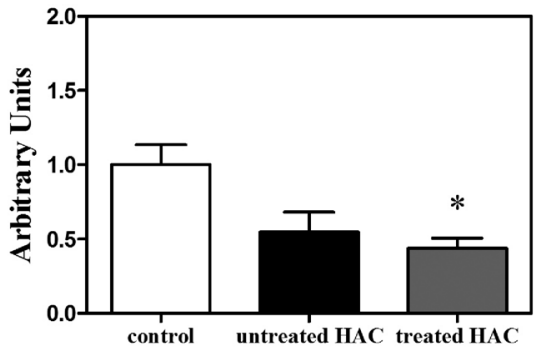

\section{PKC-lambda}

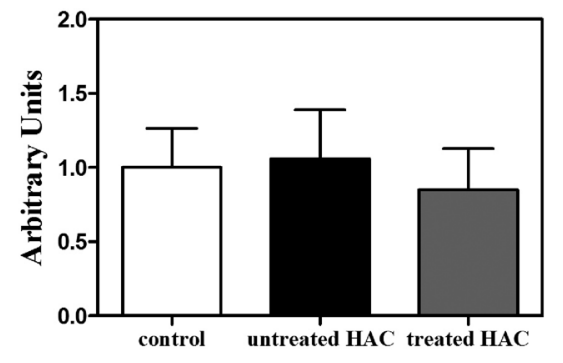

Fig. 1. Gene expressions of insulin signal molecules. Gene expressions of insulin signal molecules, such as IRS-1, IRS-2, PI3-K, Akt-2 and PKC-lambda, in neutrophils were analyzed in the control dogs $(\mathrm{n}=8)$, the untreated HAC dogs $(\mathrm{n}=5)$ and the treated HAC dogs $(\mathrm{n}=6)$. Values are expressed as means $\pm \mathrm{SEM}(* P<0.05 ; * * P<0.01$ vs. control, Kruskal-Wallis test).

glucocorticoid levels were recovered [13]. Collectively, gene expressions of insulin signal molecules, especially IRS-2, PI3-K and Akt-2, decreased in the HAC dogs, which may contribute to the induction of insulin resistance. In the current study, we have not analyzed GLUT-4 variations. The GIR of HAC dogs had been significantly lower than those of control dogs in our previous study [15], suggesting that GLUT-4 located in cell membranes had decreased in HAC dogs, although it is unclear if it decreased at a transcriptional level. A further study is necessary to clarify the transcriptional modulation of GLUT-4 in HAC dogs.

Limitation of this study lies in that the data have been collected from neutrophils. Variations of the insulin signal molecules in neutrophils might not always reflect that in other tissues, such as skeletal muscles, adipose tissues and liver. However, we have demonstrated that the insulin signal molecules mRNAs in neutrophils correlate with those in other tissues in cats previously [26], so we consider them indirect measures to assess the condition of insulin signal molecules in other tissues. Recently, it has been reported that neutrophilic elastase is associated with insulin resistance [41]. Although it is unclear if the phenomenon is connected to insulin resistance in HAC dogs in this study, insulin has biological effects on neutrophils and it might be worth pursuing in further studies.

In conclusion, it was suggested that decrease in gene expressions of insulin signal molecules may be a mechanism of insulin resistance in HAC dogs, partially, at least. We focused on the transcription of insulin signal molecules, and as for the next challenge, we should analyze the protein amounts (translation) and the phosphorylation (activation) of these molecules to get the whole story. Moreover, to reveal detailed relationships of glucocorticoid and insulin signal molecules, the study should be extended to laboratory dogs receiving glucocorticoids experimentally or clinical patients receiving glucocorticoids for medical treatment (i.e. 
autoimmune disease, inflammatory bowel disease, etc.). It is also necessary to compare the molecule actions and insulin resistance assessed by EHGC method in HAC dogs.

\section{REFERENCES}

1. Andrews, R. C. and Walker, B. R. 1999. Glucocorticoids and insulin resistance: old hormones, new targets. Clin. Sci. (Lond.) 96: 513-523. [Medline] [CrossRef]

2. Araki, E., Lipes, M. A., Patti, M. E., Bruning, J. C., Haag, B. 3rd., Johnson, R. S. and Kahn, C. R. 1994. Alternative pathway of insulin signalling in mice with targeted disruption of the IRS1 gene. Nature 372: 186-190. [Medline] [CrossRef]

3. Bandyopadhyay, G., Kanoh, Y., Sajan, M. P., Standaert, M. L. and Farese, R. V. 2000. Effects of adenoviral gene transfer of wild-type, constitutively active, and kinase-defective protein kinase C-lambda on insulin-stimulated glucose transport in L6 myotubes. Endocrinology 141: 4120-4127. [Medline]

4. Burén, J., Liu, H. X., Jensen, J. and Eriksson, J. W. 2002. Dexamethasone impairs insulin signalling and glucose transport by depletion of insulin receptor substrate-1, phosphatidylinositol 3-kinase and protein kinase B in primary cultured rat adipocytes. Eur. J. Endocrinol. 146: 419-429. [Medline] [CrossRef]

5. Burén, J., Lai, Y. C., Lundgren, M., Eriksson, J. W. and Jensen, J. 2008. Insulin action and signalling in fat and muscle from dexamethasone-treated rats. Arch. Biochem. Biophys. 474: 91-101. [Medline] [CrossRef]

6. Calera, M. R., Martinez, C., Liu, H., Jack, A. K., Birnbaum, M. J. and Pilch, P. F. 1998. Insulin increases the association of Akt-2 with Glut4-containing vesicles. J. Biol. Chem. 273: 7201-7204. [Medline] [CrossRef]

7. Campbell, J., Rastogi, K. S. and Hausler, H. R. 1966. Hyperinsulinemia with diabetes induced by cortisone, and the influence of growth hormone in the Chinese hamster. Endocrinology 79: 749-756. [Medline] [CrossRef]

8. Caperuto, L. C., Anhe, G. F., Amanso, A. M., Ribeiro, L. M., Medina, M. C., Souza, L. C., Carvalho, O. M., Bordin, S., Saad, M. J. and Carvalho, C. R. 2006. Distinct regulation of IRS proteins in adipose tissue from obese aged and dexamethasonetreated rats. Endocrine 29: 391-398. [Medline] [CrossRef]

9. Carpenter, C. L., Duckworth, B. C., Auger, K. R., Cohen, B., Schaffhausen, B. S. and Cantley, L. C. 1990. Purification and characterization of phosphoinositide 3-kinase from rat liver. $J$. Biol. Chem. 265: 19704-19711. [Medline]

10. Cavalot, F., Anfossi, G., Russo, I., Mularoni, E., Massucco, P., Burzacca, S., Mattiello, L. and Trovati, M. 1992. Insulin, at physiological concentrations, enhances the polymorphonuclear leukocyte chemotactic properties. Horm. Metab. Res. 24: 225228. [Medline] [CrossRef]

11. Dallman, M. F., Strack, A. M., Akana, S. F., Bradbury, M. J., Hanson, E. S., Scribner, K. A. and Smith, M. 1993. Feast and famine: critical role of glucocorticoids with insulin in daily energy flow. Front. Neuroendocrinol. 14: 303-347. [Medline] [CrossRef]

12. DeFronzo, R. A., Tobin, J. D. and Andres, R. 1979. Glucose clamp technique: a method for quantifying insulin secretion and resistance. Am. J. Physiol. 237: E214-E223. [Medline]

13. Dinneen, S., Alzaid, A., Miles, J. and Rizza, R. 1993. Metabolic effects of the nocturnal rise in cortisol on carbohydrate metabolism in normal humans. J. Clin. Invest. 92: 2283-2290. [Medline] [CrossRef]

14. Esmann, V. 1972. The diabetic leukocyte. Enzyme 13: 32-55. [Medline]
15. Fukuta, H., Mori, A., Urumuhan, N., Lee, P., Oda, H., Saeki, K., Kurishima, M., Nozawa, S., Mizutani, H., Mishina, S., Arai, T. and Sako, T. 2012. Characterization and Comparison of Insulin Resistance Induced by Cushing Syndrome or Diestrus against Healthy Control Dogs as Determined by euglycemic-hyperinsulinemic glucose clamp profile glucose infusion rate using an artificial pancreas apparatus. J. Vet. Med. Sci. 74: 1527-1530. [Medline] [CrossRef]

16. Giorgino, F., Almahfouz, A., Goodyear, L. J. and Smith, R. J. 1993. Glucocorticoid regulation of insulin receptor and substrate IRS-1 tyrosine phosphorylation in rat skeletal muscle in vivo. J. Clin. Invest. 91: 2020-2030. [Medline] [CrossRef]

17. Hill, M. M., Clark, S. F., Tucker, D. F., Birnbaum, M. J., James, D. E. and Macaulay, S. L. 1999. A role for protein kinase Bbeta/ Akt2 in insulin-stimulated GLUT4 translocation in adipocytes. Mol. Cell. Biol. 19: 7771-7781. [Medline]

18. Kim, J. K. 2009. Hyperinsulinemic-euglycemic clamp to assess insulin sensitivity in vivo. Methods Mol. Biol. 560: 221-238. [Medline] [CrossRef]

19. Kotani, K., Ogawa, W., Matsumoto, M., Kitamura, T., Sakaue, H., Hino, Y., Miyake, K., Sano, W., Akimoto, K., Ohno, S. and Kasuga, M. 1998. Requirement of atypical protein kinase clambda for insulin stimulation of glucose uptake but not for Akt activation in 3T3-L1 adipocytes. Mol. Cell. Biol. 18: 6971-6982. [Medline]

20. Kubota, N., Tobe, K., Terauchi, Y., Eto, K., Yamauchi, T., Suzuki, R., Tsubamoto, Y., Komeda, K., Nakano, R., Miki, H., Satoh, S., Sekihara, H., Sciacchitano, S., Lesniak, M., Aizawa, S., Nagai, R., Kimura, S., Akanuma, Y., Taylor, S. I. and Kadowaki, T. 2000. Disruption of insulin receptor substrate 2 causes type 2 diabetes because of liver insulin resistance and lack of compensatory beta-cell hyperplasia. Diabetes 49: 1880-1889. [Medline] [CrossRef]

21. Kumagai, J., Akiyama, H., Iwashita, S., Iida, H. and Yahara, I. 1981. In vitro regeneration of resting lymphocytes from stimulated lymphocytes and its inhibition by insulin. J. Immunol. 126 : 1249-1254. [Medline]

22. Lee, P., Mori, A., Coradini, M., Mori, N., Sagara, F., Yamamoto, I., Rand, J. S. and Arai, T. 2013. Potential predictive biomarkers of obesity in Burmese cats. Vet. J. 195: 221-227. [Medline] [CrossRef]

23. Maratou, E., Dimitriadis, G., Kollias, A., Boutati, E., Lambadiari, V., Mitrou, P. and Raptis, S. A. 2007. Glucose transporter expression on the plasma membrane of resting and activated white blood cells. Eur. J. Clin. Invest. 37: 282-290. [Medline] [CrossRef]

24. Marco, J., Melani, F., Goberna, R., Rott, W. H. and Pfeiffer, E. F. 1968. Effect of treatment with prednisolone on the secretion of insulin in rats. Diabetologia 4: 365-369. [Medline] [CrossRef]

25. Mori, A., Lee, P., Takemitsu, H., Sako, T. and Arai, T. 2009. Comparison of insulin signaling gene expression in insulin sensitive tissues between cats and dogs. Vet. Res. Commun. 33: 211-226. [Medline] [CrossRef]

26. Mori, A., Lee, P., Takemitsu, H., Iwasaki, E., Kimura, N., Yagishita, M., Hayasaka, M. and Arai, T. 2009. Decreased gene expression of insulin signaling genes in insulin sensitive tissues of obese cats. Vet. Res. Commun. 33: 315-329. [Medline] [CrossRef]

27. Oh, H., Siano, B. and Diamond, S. 2008. Neutrophil isolation protocol. J. Vis. Exp. 17: 745. [Medline]

28. Okuno, Y. and Gliemann, J. 1988. Effect of chemotactic factors on hexose transport in polymorphonuclear leucocytes. Biochim. Biophys. Acta 941: 157-164. [Medline] [CrossRef] 
29. Olefsky, J. M., Johnson, J., Liu, F., Jen, P. and Reaven, G. M. 1975. The effects of acute and chronic dexamethasone administration on insulin binding to isolated rat hepatocytes and adipocytes. Metabolism 24: 517-527. [Medline] [CrossRef]

30. Patti, M. E., Sun, X. J., Bruening, J. C., Araki, E., Lipes, M. A., White, M. F. and Kahn, C. R. 1995. 4PS/insulin receptor substrate (IRS)-2 is the alternative substrate of the insulin receptor in IRS-1-deficient mice. J. Biol. Chem. 270: 24670-24673. [Medline] [CrossRef]

31. Peikes, H., Morris, D. O. and Hess, R. S. 2001. Dermatologic disorders in dogs with diabetes mellitus: 45 cases (1986-2000). J. Am. Vet. Med. Assoc. 219: 203-208. [Medline] [CrossRef]

32. Perley, M. and Kipnis, D. M. 1966. Effect of glucocorticoids on plasma insulin. N. Engl. J. Med. 274: 1237-1241. [Medline] [CrossRef]

33. Peterson, M. E., Altszuler, N. and Nichols, C. E. 1984. Decreased insulin sensitivity and glucose tolerance in spontaneous canine hyperadrenocorticism. Res. Vet. Sci. 36: 177-182. [Medline]

34. Rand, J. S., Fleeman, L. M., Farrow, H. A., Appleton, D. J. and Lederer, R. 2004. Canine and feline diabetes mellitus: Nature or nurture? J. Nutr. 134: 2072S-2080S. [Medline]

35. Roep, B. O. 2003. The role of T-cells in the pathogenesis of Type 1 diabetes: from cause to cure. Diabetologia 46: 305-321. [Medline]

36. Ruzzin, J., Wagman, A. S. and Jensen, J. 2005. Glucocorticoidinduced insulin resistance in skeletal muscles: defects in insulin signalling and the effects of a selective glycogen synthase kinase-3 inhibitor. Diabetologia 48: 2119-2130. [Medline] [CrossRef]

37. Saad, M. J., Folli, F., Kahn, J. A. and Kahn, C. R. 1993. Modulation of insulin receptor, insulin receptor substrate-1, and phosphatidylinositol 3-kinase in liver and muscle of dexamethasone-treated rats. J. Clin. Invest. 92: 2065-2072. [Medline] [CrossRef]

38. Sajan, M. P., Rivas, J., Li, P., Standaert, M. L. and Farese, R. V. 2006. Repletion of atypical protein kinase C following RNA interference-mediated depletion restores insulin-stimulated glucose transport. J. Biol. Chem. 281: 17466-17473. [Medline] [CrossRef]

39. Sakoda, H., Ogihara, T., Anai, M., Funaki, M., Inukai, K., Katagiri, H., Fukushima, Y., Onishi, Y., Ono, H., Fujishiro, M., Kikuchi, M., Oka, Y. and Asano, T. 2000. Dexamethasone-induced insulin resistance in 3T3-L1 adipocytes is due to inhibition of glucose transport rather than insulin signal transduction. Diabetes 49: 1700-1708. [Medline] [CrossRef]

40. Summers, S. A., Whiteman, E. L., Cho, H., Lipfert, L. and
Birnbaum, M. J. 1999. Differentiation-dependent suppression of platelet-derived growth factor signaling in cultured adipocytes. J. Biol. Chem. 274: 23858-23867. [Medline] [CrossRef]

41. Talukdar, S., Oh, da. Y., Bandyopadhyay, G., Li, D., Xu, J., McNelis, J., Lu, M., Li, P., Yan, Q., Zhu, Y., Ofrecio, J., Lin, M., Brenner, M. B. and Olefsky, J. M. 2012. Neutrophils mediate insulin resistance in mice fed a high-fat diet through secreted elastase. Nat. Med. 18: 1407-1412. [Medline] [CrossRef]

42. Tamemoto, H., Kadowaki, T., Tobe, K., Yagi, T., Sakura, H., Hayakawa, T., Terauchi, Y., Ueki, K., Kaburagi, Y., Satoh, S., Sekihara, H., Yoshioka, S., Horikoshi, H., Furuta, Y., Ikawa, Y., Kasuga, M., Yazaki, Y. and Aizawa, S. 1994. Insulin resistance and growth retardation in mice lacking insulin receptor substrate-1. Nature 372: 182-186. [Medline] [CrossRef]

43. Tobe, K., Tamemoto, H., Yamauchi, T., Aizawa, S., Yazaki, Y. and Kadowaki, T. 1995. Identification of a $190-\mathrm{kDa}$ protein as a novel substrate for the insulin receptor kinase functionally similar to insulin receptor substrate-1. J. Biol. Chem. 270: 5698-5701. [Medline] [CrossRef]

44. Ugi, S., Imamura, T., Maegawa, H., Egawa, K., Yoshizaki, T., Shi, K., Obata, T., Ebina, Y., Kashiwagi, A. and Olefsky, J. M. 2004. Protein phosphatase 2 A negatively regulates insulin's metabolic signaling pathway by inhibiting Akt (protein kinase B) activity in 3T3-L1 adipocytes. Mol. Cell. Biol. 24: 8778-8789. [Medline] [CrossRef]

45. Wang, X. X., Li, W. and Liu, Y. C. 2010. Controlling effect of berberine on in vitro synthesis and metabolism of steroid hormones in insulin resistant ovary. Zhongguo Zhong Xi Yi Jie He Za Zhi 30: 161-166. [Medline]

46. Weinstein, S. P., Wilson, C. M., Pritsker, A. and Cushman, S. W. 1998. Dexamethasone inhibits insulin-stimulated recruitment of GLUT4 to the cell surface in rat skeletal muscle. Metabolism 47: 3-6. [Medline] [CrossRef]

47. Whelan, J. A., Russell, N. B. and Whelan, M. A. 2003. A method for the absolute quantification of cDNA using real-time PCR. $J$. Immunol. Methods 278: 261-269. [Medline] [CrossRef]

48. White, M. F. 1998. The IRS-signalling system: a network of docking proteins that mediate insulin action. Mol. Cell. Biochem. 182: 3-11. [Medline] [CrossRef]

49. Yamauchi, T., Tobe, K., Tamemoto, H., Ueki, K., Kaburagi, Y., Yamamoto-Honda, R., Takahashi, Y., Yoshizawa, F., Aizawa, S., Akanuma, Y., Sonenberg, N., Yazaki, Y. and Kadowaki, T. 1996. Insulin signalling and insulin actions in the muscles and livers of insulin-resistant, insulin receptor substrate 1-deficient mice. Mol. Cell. Biol. 16: 3074-3084. [Medline] 